\title{
Dividend Signalling Hypothesis In Emerging Markets: More Empirical Evidence
}

\author{
Wasim K. Al-Shattarat, Gulf University for Science and Technology (GUST) - Kuwait \\ Muhannad A. Atmeh, German Jordanian University (GJU), Jordan \\ Basiem K. Al-Shattarat, Coventry University, UK
}

\begin{abstract}
The main objective of this study is to examine empirically the signalling theory for a sample of firms listed at Amman Stock Exchange (ASE) during the period 2005 to 2010. The sample consists of 183 observations and 132 observations for dividend release sample and no-dividend release sample, respectively. Event Study Methodology (ESM) is applied to examine the market reaction to dividend release announcements. The market model is used to generate the expected returns. Also, the t-test is used to examine the significance of the mean and cumulative abnormal returns. Results from the dividend release sample shows that there is a significant positive abnormal return on the announcement days. Also, it shows that there is an overreaction straight after the announcement day, then a correcting attempt in the post event and then it goes back to normal, which is consistent with the signalling hypothesis. For the no-dividend release sample, the results show no significant abnormal return on and around the announcement days which is again consistent with the signalling hypothesis. Our results are consistent with Al-Shattarat et al. (2012) suggestions that there could be value relevance for dividends rather than dividends' change. Our findings show that there is value relevance for dividends and thus supporting the signalling hypothesis.
\end{abstract}

Keywords: Dividend Announcement; Signalling Hypothesis; Amman Stock Exchange

\section{INTRODUCTION}

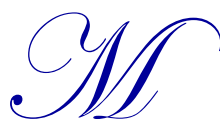

iller and Modigliani (1961) demonstrated that, the market value of a firm has no reliance on its dividend policy within a perfect stock market. They mentioned that the firm's earning and investment affects only the market value and dividend policy have nothing to do with its market value. After Miller and Modigliani theory, many researches try to explain that dividend matters, and they tried to link it with the value of the firm, they call it dividend irrelevance hypothesis. Researchers tried to explain the dividend policy under different hypothesis namely; Bird in the Hand theory, agency cost theory, tax clientele theory and signalling theory. These theories tried to clarify the behaviour of dividend policy determined by corporate managers. Miller and Modigliani's theory was based on perfect market; while with imperfect markets, dividends matters.

The results from the empirical literature show that the dividend pay-out decision is complex, and cannot be characterised by any one theory. Pettit (1972) in his pioneering study investigated the efficiency of market reaction which comes from dividends announcements. Market reaction of dividend announcements was tested by investigating abnormal returns around dividend change release dates. Charest (1978) documented the risk and return behaviour of ordinary shares following dividends announcements in NYSE for the period 1947 to 1967. Using large unexpected dividend changes, he showed a 5.37 percent positive abnormal return over twelve months after the changes for the dividend increase group, and a -12.9 percent negative abnormal price adjustment over the same period for the dividend decrease group. He concluded that the NYSE fails to adjust fully to dividend information within a reasonable period. Furthermore, his findings revealed abnormal return equals to 1\%. Eades et al. (1985) 
compared their results to those of Charest (1978) and found similar results to dividend increases and no evidence for sluggish market response to dividend decreases.

Aharony and Swary (1980) studied dividend announcements rather than earning announcements. They found out insignificant effect of dividend announcements. Over the announcement period which is 2 days, they reported a significant abnormal return for the dividend increase sample. Their conclusion supported the semi-strong efficient market hypothesis. In the argument of how the market reacts over a period followed the dividend announcements. Some of studies provide evidence of post-announcement drifts for dividend change. Dielman and Oppenheimer (1984) found that prices continue to adjust for approximately one month following large dividend changes. Michaely et al. (1995) found that price continue to drift after dividend initiations and omissions. Bae (1996) investigated the possibility that post-announcement drifts accompany dividend changes. Their results indicated that statistically significant post-announcement drifts were present for quarterly dividend changes and that these drifts were not an artefact of similar drifts reported previously for earnings announcements. Although these studies report a significant reaction to dividend releases during the announcement period, they provided inconsistent results about the duration of post-announcement reactions.

McCaffrey and Hamill (2000) examined the price reaction to dividend initiations announcements by IPO in the UK. Their data consisted of 131 official listed (OL) and 139 unlisted between 1982 and 1991 . They found a positive abnormal return around dividend initiation announcements. Furthermore, they found that unpredicted earnings are significant and positive in relation to the date of announcement and unpredicted dividends are significantly positively related to official listed sample only. McClusket $e t$ al. (2006) provided support from the Irish stock exchange. They found minor value-relevant of dividends announcements. Fukuda (2000) investigated the abnormal stock returns right after dividend. Applying annual data from Japanese stock market for the period 1990 to 1994, he found that the market reacts positively for dividend increases, and negatively for dividend decreases. Furthermore, a study examining one of the emerging markets (Cyprus) was held by Travlos et al. (2001), they examined the market reaction to dividend increase and stock dividends in Cyprus. They elicited a significant positive abnormal return for the both events. Their study contended that special characteristics of the Cyprus stock market delimit applicability of most traditional explanations for cash and stock dividends in favour of an information signalling explanation. In another emerging market, Dasilas (2007) documented a significant market reaction on dividend announcements dates when studying Athens capital market for the period to 2004. His results lend to support the signalling hypothesis. In the Jordanian market, Al-Shattarat et al. (2012) investigated the market reaction to dividend change announcements for a sample of firms. They used the ESM covering the period 2000 to 2006. Their findings did not support the signalling hypothesis for dividend change and their suggestion was that market might react to dividends rather than to the change in dividends. Therefore, the value relevance could be related to the release of dividends which might need further investigation.

Overall, current and previous studies have focused typically on investigating dividend policy in developed markets, especially the US and European markets. Relatively limited evidence exists in relation to emerging markets. This suggests that more work needs to be carried out on dividend policy in emerging markets. Therefore, this study builds upon the aforementioned studies especially Al-Shattarat et al. (2012) who suggested further investigation on the area of signalling hypothesis to fulfil the gap of market reaction studies to dividend policy in the Jordanian market.

The remainder of this study is structured in the following manner. Section 2 highlights data and methodology employed, while section 3 presents empirical results. The final section, 4, outlines the conclusion.

\section{DATA AND METHODOLOGY}

This study spans over six years from 2005 to 2010 covering all the industrial firms. The initial sample consists of 78 industrial firms listed on ASE in the year 2010. Observations are excluded from the sample if there are introduced, reintroduced or fall in bankruptcy. Also, observations are excluded from the sample if other event announcements are made contemporaneously with dividend announcements, or if it does not have announcement day or data is not available. The final sample leads to 315 observations distributed to 183 observations of those relating to dividend release announcements and 132 observations related to no dividends. 
The event study methodology is employed in this study to examine the signalling hypothesis of dividend announcements. Firstly, this study adopted the general assembly meeting date as an event date, because on that date dividends are approved officially. Secondly, we used 100 trading daily observations as the estimation period from day $T=-11$ to Time $l=-110$ before the event period and the event period of 11 trading days, covering the period $T+l=-5$ before to $T+m=+5$ after the announcement day is employed in this study. Thirdly, the daily returns are calculated as the natural logarithms of the stock price relatives given by the equation below.

$$
R_{i, t}=\log _{e}\left(P_{i, t}+D_{i, t}\right)-\log _{e} P_{i, t-1}
$$

where,

$>R_{i, t} \quad$ is the daily stock returns for security $i$ at day $t$.

$>\log _{e} P_{i, t-1}$ is the natural logarithm of the stock price $i$ at day $t-1$.

$>\log _{e} P_{i, t}$ is the natural logarithm of the stock price $i$ at day $t$.

$>D_{i, t} \quad$ is the dividend on security $i$ at day $t$.

The returns on ASE index are computed as the natural logarithm of the first differences of the market index according to the equation below.

$$
R_{m, t}=\log _{e} I_{t}-\log _{e} I_{t-1}
$$

where,

$>R_{m, t}$ is the market return at day $t$.

$>\log _{e} I_{t-1}$ is the natural logarithm price index of the market at the end of day $t-1$.

$>\log _{e} I_{t}$ is the natural logarithm of price index of the market at the end of day $t$.

Then, the market model is used to generate the expected returns as follows:

$$
R_{i, t}=\alpha+\beta R_{m, t}+\varepsilon_{i, t}
$$

Where

$$
\begin{array}{lll}
> & R_{i, t} & \text { is the daily returns of security } i \text { at day } t . \\
> & R_{m, t} & \text { is the daily returns on ASE index at day } t . \\
> & \varepsilon_{i, t} & \text { is the residual (abnormal return) of security } i \text { at day } t . \\
> & \alpha \text { and } \beta & \text { is the parameter estimates of the market model. }
\end{array}
$$

where,

$$
\begin{aligned}
& >\quad \beta=\operatorname{cov}\left(R_{i, t}, R_{m, t}\right) / \operatorname{var}\left(R_{m, t}\right), \text { and } \\
& >\quad \alpha=E\left(R_{i, t}\right)-\beta E\left(R_{m, t}\right)
\end{aligned}
$$

The residual (abnormal returns) $\varepsilon_{i, t}$, therefore, is calculated from the following equation:

$$
\varepsilon_{i, t}=R_{i, t}-\hat{R}_{i, t}
$$


where,

$>\varepsilon_{i, t}$ is the excess (abnormal) return of firm $i$ at day $t$.

$>\quad R_{i, t}$ is the actual (raw) return of firm $i$ at day $t$.

$>\hat{R}_{i, t}$ is the estimated return of firms $i$ at day $t$.

The abnormal return averages individual observations as follows:

$$
A R_{t}=1 / N \sum_{i=1}^{N} \varepsilon_{i, t}
$$

where,

$>A R_{t}$ is the average abnormal return at day $t$.

$>N$ is the number of observations.

$>\varepsilon_{i, t}$ is the abnormal return of firm $i$ at day $t$.

The CAR over holding periods, from day $m 1$ to day $m 2$, is calculated as follows:

$$
C A R_{m_{1}, m_{2}}=\sum_{t=m_{1}}^{m_{2}} A R_{t}
$$

where,

$>C A R_{m_{1}, m_{2}}$ is the cumulative abnormal return over the holding period $m 1$ to $m 2$.

3

\section{EMPIRICAL RESULTS}

Table 1 summarizes the expectation of the two samples; dividend release and no dividend release. This study expects to have a positive price impact to dividend release on the announcement day, and no price impact for the no-release sample. This will be interpreted by the market as a signal that managers have insider information about the firm's earnings. While before the announcement day, no price impact is expected, this is indication of no information leakage. Table 1 presents a summary of the main expectations regarding the two samples, dividend release and no dividend release samples.

Table 1: Summary of the Expected Mean Abnormal Return and Cumulative Abnormal Return

\begin{tabular}{lccc}
\hline \multicolumn{1}{c}{ Dividend } & Expected $M A R_{(\tau=0)}$ & \multicolumn{2}{c}{ Expected $C A R_{m 1, m 2}=0$} \\
& & Per-event & Post-event \\
\hline $\begin{array}{l}\text { Dividend } \\
\text { Released }\end{array}$ & Positive: MAR>0 & No Change: $C A R_{-5,-1}=0$ & Positive: $C A R_{0,5}>0$ \\
$\begin{array}{l}\text { No Dividend } \\
\text { Released }\end{array}$ & No change: MAR=0 & No Change: $C A R_{-5,-1}=0$ & No Change: $C A R_{0,5}=0$ \\
\hline
\end{tabular}

Table 2 reports a summary of the results for the market model. Table 2 shows the mean abnormal return percent (MAR \%), its associated $t$-statistics and its p-value (the significance of MAR) on and around the announcement date of the dividend release sample. Column 1 shows the test period days, 5 days before the dividend announcement and 5 days after the dividend announcement, which takes day 0 as an event date. Columns 2, 3 and 4 shows (MAR \%) employing the market model, $t$-statistics and p-value respectively. Significant abnormal return is 
observed on days 0 and 1 at $1 \%$ significant level. The mean abnormal return is $3.095 \%$ and $-0.669 \%$ with a $t$ statistics 20.98 and -4.53 , respectively. Even the market reacts negatively to dividend release on day 1 , the overall market reaction on day 0 and 1 is positive. This leads to accept the hypothesis that there is a significant positive abnormal return on the dividend release announcement days, table 2 shows that there is an overreaction straight after the announcement day, then a correcting attempt in the post event and then it goes back to normal. As a result, the market reacts positively to dividend announcements, which is consistent with the signalling hypothesis.

Columns 5, 6 and 7 in Table 2 show (MAR \%) employing the market model, $t$-statistics and its $p$-value (the significance of MAR) for the no-dividend release sample, respectively. No significant abnormal return is observed on and around the announcement days. The overall MAR on the post announcement is not high and significant. This leads to support the signalling hypothesis and to accept the hypothesis for the no-dividend release sample that there is no significant change on the abnormal return on and around the announcement days.

Table 2: Mean Abnormal Return of Dividend Release and no Release samples

\begin{tabular}{|c|c|c|c|c|c|c|}
\hline \multirow{3}{*}{ Days } & \multirow{2}{*}{\multicolumn{3}{|c|}{$\begin{array}{l}\text { Dividend Release Sample } \\
\mathrm{N}=\mathbf{1 8 3}\end{array}$}} & \multicolumn{3}{|c|}{ No-Dividend Release Sample } \\
\hline & & & & & $\mathbf{N}=13$ & \\
\hline & MAR \% & t-test & P-value & MAR \% & t-test & P-value \\
\hline-5 & 0.050 & 0.34 & 0.366 & -0.058 & -0.28 & 0.776 \\
\hline-4 & 0.030 & 0.20 & 0.421 & 0.246 & 1.20 & 0.115 \\
\hline-3 & 0.040 & 0.27 & 0.394 & 0.023 & 0.11 & 0.456 \\
\hline-2 & -0.038 & -0.26 & 0.795 & 0.170 & 0.83 & 0.204 \\
\hline-1 & 0.084 & 0.57 & 0.284 & -0.180 & -0.88 & 0.380 \\
\hline 0 & $3.095 * *$ & 20.98 & 0.000 & 0.005 & 0.02 & 0.491 \\
\hline 1 & $-0.669 * *$ & -4.53 & 0.000 & -0.011 & -0.05 & 0.958 \\
\hline 2 & $-0.308 *$ & -2.09 & 0.037 & -0.049 & -0.24 & 0.813 \\
\hline 3 & 0.155 & 1.05 & 0.147 & 0.077 & 0.38 & 0.354 \\
\hline 4 & -0.208 & -1.41 & 0.159 & $0.490 * *$ & 2.38 & 0.009 \\
\hline 5 & $0.306^{*}$ & 2.07 & 0.019 & 0.298 & 1.45 & 0.073 \\
\hline
\end{tabular}

* Significant at the 5 percent level, ** Significant at the 1 percent level, MAR values are in percentage

Figure 1 shows graphically the mean abnormal return (MAR) for dividend release sample. It shows that the market reaction is positively related to dividend release announcements. Graphically, the market reacts positively to its highest point when announcing dividends, which is around 3\% Abnormal Return on day 0. Also, Figure 1 shows that there is no information leakage before the announcement day. Figure 1 is presented below.

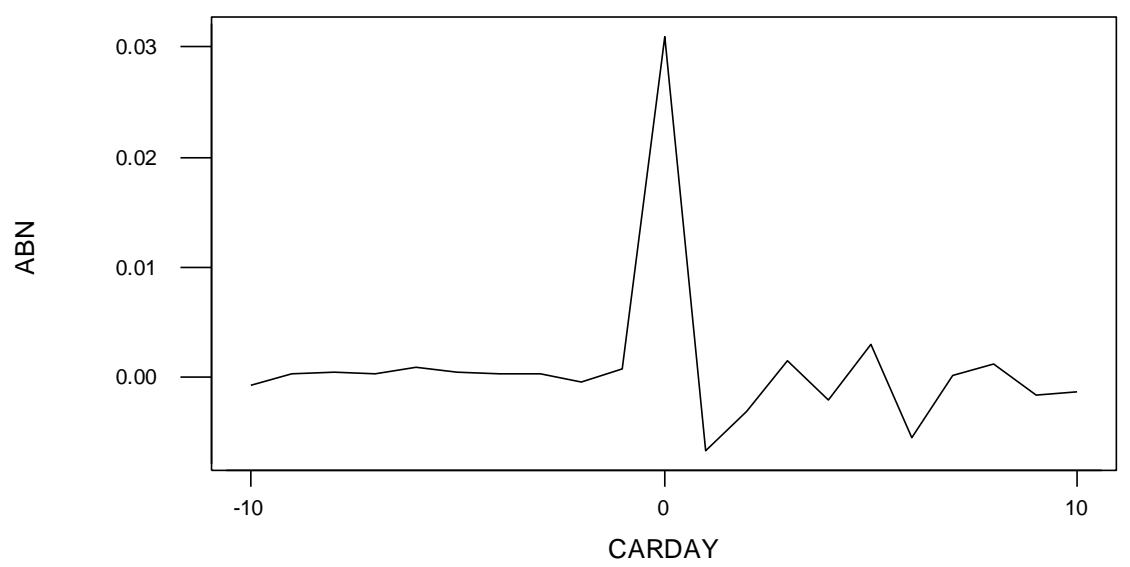

Figure 1 
Figure 2 shows graphically the mean abnormal return (MAR) for no-dividend release sample. It shows that the market reaction is constant for the period \pm 5 days. Graphically, the market reaction is around 0 leading to support the signalling hypothesis, this strengthening the previous suggestion that there is support for the signalling hypothesis. Figure 2 shows that there is no information leakage before the announcement day. Figure 2 is presented below.

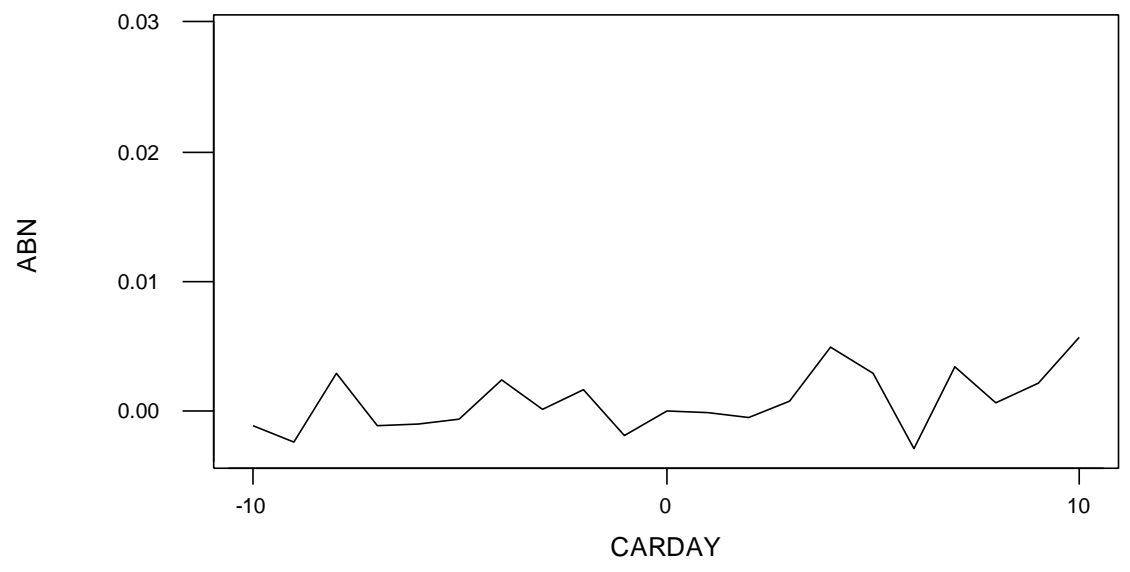

Figure 2

Table 3 reports a summary of the mean cumulative abnormal return on and around the announcement date for dividend announcements (dividend release and no-dividend release samples). T-statistics test is used to report the results. The cumulative abnormal returns are based on the market model. Column 1 reports the test-holding period used, the holding period used to test the significance is before 5 days and after 5 days of the event (the whole test period). Column 2, 3 and 4 reports the cumulative abnormal return, its t- statistics and its p-value for the dividend release sample. It shows that CAR is $1.976 \%$ with t-test 3.00 , positively significant at $1 \%$ level. This result lead to accept the hypothesis that there is a significant positive cumulative abnormal return related to dividend release announcements. Again, this result reported from CAR support the signalling hypothesis.

Column 5, 6 and 7 reports the cumulative abnormal return, t-test statistics and p-value for the no-dividend release sample. No significance are reported in the test period taken. This result leads to accept the hypothesis that there is not a significant change on the cumulative abnormal return after the no-dividend release announcements. Again, this result reported from CAR support the signalling hypothesis. Overall, the results show that the market reacts significantly to dividend release on the announcement day.

Table 3: Summary of the Cumulative Abnormal Return on and around the Dividend Announcements

\begin{tabular}{ccccccc}
\hline $\begin{array}{c}\text { Holding } \\
\text { Period }\end{array}$ & CAR \% & $\begin{array}{c}\text { Dividend Release Sample } \\
\text { N=183 } \\
\text { t-test }\end{array}$ & P-value & CAR\% & $\begin{array}{c}\text { No Dividend Release Sample } \\
\text { N=132 } \\
\text { t-test }\end{array}$ & P-value \\
\hline$(-5,5)$ & $1.976^{* *}$ & 3.00 & 0.001 & 0.674 & 0.87 & 0.331 \\
\hline
\end{tabular}

* Significant at the 5 percent level, ** Significant at the 1 percent level, CAR values are in percentage

\section{CONCLUSION}

The main objective of this study is to examine empirically the signalling theory for a sample of firms listed at Amman Stock Exchange (ASE) during the period 2005 to 2010. The sample consists of 183 observations and 132 observations for dividend release sample and no-dividend release sample, respectively. The Event Study Methodology (ESM) is applied to examine the market reaction to dividend release announcements. The market 
model is used to generate the expected returns. Also, the $t$-test is used to examine the significance of the mean and cumulative abnormal returns. Results from the dividend release sample shows that there is a significant positive abnormal return on the announcement days. Also, it shows that there is an overreaction straight after the announcement day, then a correcting attempt in the post event and then it goes back to normal, which is consistent with the signalling hypothesis. For the no-dividend release sample, the results show no significant abnormal return on and around the announcement days which is again consistent with the signalling hypothesis. Our results are consistent with Al-Shattarat et al. (2012) suggestions that there could be value relevance for dividends rather than dividends' change. Our findings show that there is value relevance for dividends and thus supporting the signalling hypothesis.

\section{AUTHOR INFORMATION}

Wasim K. Al-Shattarat is an Assistant Professor of Accounting at Gulf University for Science and Technology (GUST), Kuwait. He received his PhD in Accounting from Queen's University of Belfast, UK. His research interests are Accounting Information, Corporate Governance, Dividend Policy, Cost of Capital and Disclosure. E-mail: shattarat.w@gust.edu.kw (Corresponding author)

Muhannad A. Atmeh is an Assistant Professor of Accounting at German Jordanian University, Jordan. He received his $\mathrm{PhD}$ in Accounting and finance from Newcastle University, UK. His research interests are Financial Accounting, Auditing, and Islamic Accounting. E-mail: Muhannad.atmeh@gju.edu.jo

Basiem K. Al-Shattarat is completing his postgraduate studies in accounting and finance at Coventry University, UK. His research interests are Accounting Information and IFRS. E-mail: basiem.2006@ hotmail.com

\section{REFERENCES}

1. Aharony, J. and Swary, I. (1980). "Quarterly Dividend and Earning Announcements and Stockholders' Returns: An Empirical Analysis." The Journal of Finance 35(1): 1-12.

2. Al-Shattarat, W., Al-Khasawneh, J. and Al-Shattarat, H. (2012) "Market Reaction To Changes In Dividend Payments Policy In Jordan”, Journal of Applied Business Research 28(6).

3. Bae, G. (1996). "Post-Announcement Drifts Associated with Dividend Changes." The Journal of Financial Research XIX(4): 541-559.

4. Charest, G. (1978). "Dividend Information, Stock Returns and Market Efficiency-II." Journal of Financial Economics 6: 297-330.

5. Dasilas, A. (2007). Stock Market Reaction to Dividend Announcements: Evidence from the Greek Stock Market. SSRN eLibrary, SSRN.

6. Dielman, T. and H. Oppenheimer (1984). "An Examination of Investor Behaviour During Periods of Large Dividend Changes." Journal of Financial and Quantitative Analysis 19(2): 197-216.

7. $\quad$ Eades, K., P. Hess, et al. (1985). "Market Rationality and Dividend Announcements." Journal of Financial Economics 14: 581-604.

8. $\quad$ Easton, S. (1991). "Earnings and Dividends: Is There Any Interaction Effect?" Journal of Business Finance and Accounting 18(2): 255-266.

9. McCaffrey, K. and P. Hamill (2000). "Dividend Initiation Announcements Effects in Initial Public Offerings." Applied Financial Economics 10: 533-542.

10. McCluskey, T., M. Burton, B. and Sinclair, C. (2006). "Evidence on the Irish Stock Market's Reaction to Dividend Announcements." Applied Financial Economics 16(8): 617 - 628.

11. Michaely, R., R. Thaler, et al. (1995). "Price Reaction to Dividend Initiation and Omissions: Overreaction and Drift?" The Journal of Finance L(2): 573-608.

12. Miller, M. and F. Modigliani (1961). "Dividend Policy, Growth, and the Valuations of Shares." The Journal of Business XXXIV(4): 411-433.

13. Pettit, R. (1972). "Dividend Announcements, Security Performance, and Capital Market Efficiency." The Journal of Finance XXVII(5): 993-1007.

14. Travlos, N., Trigeorgis, L. and Vafeas, N. (2001). "Shareholder Wealth Effects of Dividend Policy Changes in an Emerging Stock Market: The Case of Cyprus." Multinational Finance Journal 5(2): 87-112. 


\section{NOTES}

